\title{
Infection of cattle with Border disease virus by sheep on communal alpine pastures
}

\author{
Braun, Ueli ; Bachofen, Claudia ; Büchi, Romain ; Hässig, Michael ; Peterhans, E
}

\begin{abstract}
The purpose of this study was to investigate whether sheep grazing communal alpine pastures with cattle can transmit Border disease virus (BDV) to cattle. A total of 1170 sheep and 923 cattle were tested for BDV using RT-PCR (sheep) and for pestivirus antibodies using an ELISA (cattle), respectively, before being moved to one of 4 pastures (A, B, C and D). Eight sheep from pasture C were viraemic. 396 of 923 cattle examined before the pasture season were seronegative. The latter were re-examined after the pasture season and 99 were seropositive or indeterminate. Antibody specificity was determined in 25 of these using a serum neutralization test (SNT). BDV infection was confirmed in 10 cattle and was considered likely in 8 others. BVDV infection was confirmed in 4 cattle and considered likely in 3 after pasturing. The study has shown that the transmission of BDV from sheep to cattle is possible on communal alpine pastures.
\end{abstract}

DOI: https://doi.org/10.1024/0036-7281/a000428

Posted at the Zurich Open Repository and Archive, University of Zurich

ZORA URL: https://doi.org/10.5167/uzh-76948

Journal Article

Accepted Version

Originally published at:

Braun, Ueli; Bachofen, Claudia; Büchi, Romain; Hässig, Michael; Peterhans, E (2013). Infection of cattle with Border disease virus by sheep on communal alpine pastures. Schweizer Archiv für Tierheilkunde, 155(2):123-128.

DOI: https://doi.org/10.1024/0036-7281/a000428 
1 Infection of cattle with Border disease virus by sheep on communal alpine pastures

U. Braun ${ }^{1}$, C. Bachofen ${ }^{2}$, R. Büchi ${ }^{1}$, M. Hässig ${ }^{1}$, E. Peterhans ${ }^{2}$

${ }^{1}$ Department of Farm Animals, University of Zurich, ${ }^{2}$ Institute of Veterinary Virology, University of Berne cattle can transmit Border disease virus (BDV) to cattle. A total of 1170 sheep and 923 cattle were tested for BDV using RT-PCR (sheep) and for pestivirus antibodies using an ELISA (cattle), respectively, before being moved to one of 4 pastures (A, B, C and D). Eight sheep from pasture C were viraemic. 396 of 923 cattle examined before the pasture season were seronegative. The latter were re-examined after the pasture season and 99 were seropositive or indeterminate. Antibody specificity was determined in 25 of these using a serum neutralization test (SNT). BDV infection was confirmed in 10 cattle and was considered likely in 8 others. BVDV infection was confirmed in 4 cattle and considered likely in 3 after pasturing. The study has shown that the transmission of BDV

Keywords: sheep, cattle, communal alpine pasture, border disease, bovine viral diarrhoea

\section{Infektion von Rindern durch Schafe auf Alpweiden mit Border-Disease-Virus}

In der vorliegenden Arbeit wurde abgeklärt, ob das Border-Disease-Virus (BD-Virus, BDV) während der gemeinsamen Alpung von Schafen und Rindern auf das Rind übertragen werden kann. Dazu wurden die auf vier Alpen (A, B, C, D) zur Sömmerung angemeldeten 1170 Schafe mittels RT-PCR auf BD-Virus und die 923 Rinder serologisch auf Pestivirus-Antikörper untersucht. Bei 8 Schafen der Alp C konnte in den Blutproben BD-Virus nachgewiesen werden. Von 923 untersuchten Rindern waren vor der Alpung 396 Rinder mittels ELISA seronegativ getestet worden. Diese Tiere wurden nach der Alpung erneut untersucht und bei 99 Rindern wurden dabei Pestivirus-Antikörper im Blut nachgewiesen oder der Befund war für eine Infektion sehr verdächtig. Bei 25 dieser Tiere konnte die Spezifität der Antikörper mittels Serumneutralisationstest (SNT) genauer bestimmt werden. Aufgrund der SNT-Untersuchung galt eine Infektion mit dem BD-Virus bei 10 Rindern als sicher und bei 8 Rindern wurde sie vermutet. Im Bezug auf BVDV (Bovine Virusdiarrhoe) wurde eine Infektion bei 4 
gemeinsamer Alpung von Schafen und Rindern eine Infektion von Rindern durch Schafe mit dem

36 Border Disease-Virus möglich ist.

Schlüsselwörter: Schaf, Rind, Alpung, Border Disease, Bovine Virusdiarrhoe

\section{Introduction}

41 Pestiviruses occur in many ruminant populations throughout the world. Bovine viral diarrhoea virus 42 (BVD virus, BVDV) affects cattle and Border disease (BD virus, BDV) principally affects sheep.

43 Pestiviruses have the ability of interspecies transmissibility. Recent studies (Krametter-Frötscher et al., 2008; Reichle, 2009; Büchi, 2009) have indicated that BDV can be transmitted from persistently infected sheep to cattle that are co-pastured with sheep. The first report (Cranwell et al., 2007) of cattle infected with BDV was from Great Britain and involved three animals. The first was a 13month old heifer with diarrhoea and weight loss, the second was a 2.5-year old cow with diarrhoea and other signs of mucosal disease and the third was a small weak newborn calf that died soon after birth. Another recent report (Strong et al., 2010) of 5 cattle infected with BDV was also from Great Britain. Research on the eradication of BVD in Switzerland carried out at the Institute of Veterinary Virology, University of Berne, found several calves persistently infected with BDV. These calves tested positive for pestiviruses in ear punch biopsy samples and subsequently in blood samples and sequencing confirmed persistent infection with BDV, rather than BVDV. Taken together these reports suggest that the presumed natural resistance of cattle against BDV no longer holds true (Strong et al., 2010). Because the seroprevalence of BDV infection of sheep in Switzerland is considerable (20\% in registered flocks and $65 \%$ in large mixed flocks; Schaller et al., 2000), the occurrence of persistently-infected sheep and ongoing transmission of the virus to other sheep must be assumed. Furthermore, it is very likely that in Switzerland sheep will be an important source of pestiviruses for cattle that are pastured or housed with sheep. This is because the program for eradication of BDV, which was started in 2008 , will soon be completed. It is suspected that analogous to the spread of BVDV among cattle (Braun et al., 1998) and BDV among sheep and goats

62 (Krametter-Frötscher et al., 2007), communal alpine pasturing plays a role in the transmission of

63 BDV from sheep to cattle. Thus, in addition to generating scientific interest, the transmission of pestiviruses from sheep to cattle has considerable practical relevance. The goal of the present study was to investigate whether BDV is transmitted from sheep to cattle under natural conditions during communal alpine pasturing, and whether infection of seronegative cattle leads to seroconversion during the pasture period. 
70 Communal alpine pastures

71 The study included 4 alpine pastures (A, B, C, D) in the cantons Schwyz, Uri and Obwalden used 72 during the summer of 2008 (Tab. 1). The pastures were 1000 to $2300 \mathrm{~m}$ above sea level and varied 73 from 200 to 800 ha (mean, 400 ha). All 4 alpine pastures were grazed by cattle and sheep for 86 to 74104 days (mean, 94 days) during the summer.

76 Sheep

77 There was a total of 1170 sheep of all ages from 29 private flocks on the 4 pastures. The number of 78 sheep per flock ranged from 7 to 300 sheep (mean, 40.3 sheep) and most were "Weisses Alpenschaf" sheep.

81 Cattle

82 There was a total of 923 cattle between 5 months and 13.8 years old (mean $\pm \mathrm{sd}=29.1 \pm 21.18$

83 months) from 94 herds. The majority $(\mathrm{n}=825,89.4 \%)$ were Swiss Braunvieh and the remaining 98 84 included utility crossbreeds $(n=23)$, Simmental $(n=23)$, Limousin $(n=14)$ and others $(n=18)$. All 85 tested negative for pestivirus antigen under the ongoing BVD eradication program.

Blood testing of sheep

In all sheep, $6 \mathrm{ml}$ blood was collected from a jugular vein into an evacuated EDTA tube (Vacuette,

89 Greiner Bio-One $\mathrm{GmbH}$, A-Kremsmünster) to test for Border disease antigen before communal 90 pasturing.

Blood testing of cattle

93 In all cattle, a blood sample was collected from the coccygeal vessels for determination of antibody

94 titre to pestivirus before communal pasturing. From 380 animals that were seronegative, a second

95 blood sample was collected at the end of pasturing to test for seroconversion. Sixteen animals that

96 were seronegative in the first test could not be re-tested because they died or were slaughtered or 97 sold.

99 Detection of viral RNA in the blood of sheep

100 This test was carried out at the Institute of Veterinary Virology, University of Berne, using 101 quantitative RT-PCR as recently described (Büchi, 2009). 
103 ELISA and serum neutralisation

104 Serological testing using ELISA was carried out at the same laboratory (Büchi, 2009). Cattle with a

105 negative ELISA result in the first sample that had a positive or indeterminate result in the second

106 sample underwent a serum neutralisation test (SNT) (Büchi, 2009) to identify the pestivirus for which

107 the animal had seroconverted. Because of genetic similarities between BVDV and BDV, some degree

108 of cross-neutralisation is expected. A BDV titre that was at least twice as high as the BVDV titre

109 confirmed BDV infection, and a titre that was higher than but not twice as high as the BVDV titre

110 indicated a likely BDV infection. The assessment of BVDV titres was analogous.

112 Statistical analysis

113 The program StatView 5.1 (SAS Institute, Wangen, Switzerland) was used for statistical evaluation.

114 The means, standard deviations and frequency distributions were calculated for the variables studied

115 and differences were analysed using analysis of variance (ANOVA) and the Bonferroni-Dunn post

116 hoc test. The Wilk Shapiro test was used to test distributions for normality. Results of normally

117 distributed variables are given as mean \pm standard deviation and results of variables with a skewed

118 distribution as median and range. The level of significance was set at $\mathrm{P}<0.05$.

120 Results

121 Virus prevalence in sheep

122 Border disease virus was detected in 8 of $1170(0.68 \%)$ clinically healthy sheep; 5 had a very high 123 viral load and 3 had a weak positive result. These 8 sheep originated from 2 flocks and all were on 124 pasture $\mathrm{C}$ (Tab. 2). The flock prevalence on pasture $\mathrm{C}$ was $6.9 \%$. The other 3 communal pastures 125 were free of BDV-positive sheep. In the 5 sheep with a high viral load, the virus was characterized 126 using sequencing; four viruses belonged to the Swiss BDV subgroup (Reichert, 2009; Peterhans et al., 127 2010) and the remaining case was BD-3-virus.

129 Seroprevalence of cattle before pasturing

130 Of the 923 cattle tested using ELISA, 396 (42.9\%) were seronegative and 527 (57.1\%) were

131 seropositive. The seroprevalence varied from 45.1 to $74.7 \%$ among the four pastures (D $45.1 \%, \mathrm{C}$

$13256.8 \%$, A $59.4 \%$, B $74.7 \%)$.

134 Seroprevalence of cattle after pasturing 
135 Of the 380 cattle that underwent a second ELISA after pasturing (16 animals were not available for 136 re-testing), 52 had a positive and 47 had an indeterminate result. Of these 99 animals with confirmed 137 or likely seroconversion, 70 were from pasture C, where the BDV-positive sheep were diagnosed. Of 138 the remaining 29 animals, 20, 6 and 3 were from pastures D, A and B, respectively.

139 Serum neutralisation testing of the 99 samples from cattle with confirmed or likely seroconversion 140 revealed 47 samples in which the antibody could not be differentiated because the BVDV and BDV 141 titres were similar, and 27 samples that were negative (Tab. 3). Differentiation of the antibody was 142 possible in the remaining 25 samples. In 10 samples the BDV titre was at least twice as high as the 143 BVD titre, confirming BDV infection. In 8 samples, the BDV titre was clearly higher than, but not 144 double, the BVD titre and BDV infection was considered likely. In 4 samples the BVDV titre was at least twice as high as the BDV titre, confirming BVDV infection, and in the remaining 3 samples, the

146 BVDV titre was clearly higher than, but not double, the BDV titre and BVDV infection was

147 considered likely. Of the 18 cattle with confirmed or likely BDV infection, 13 were from pasture C

148 and 5 from pasture D. Of the cattle that acquired BVDV infection, 4 were from pasture $\mathrm{C}$ and 3 from 149 pasture D.

\section{Discussion}

152 Border disease virus was detected in blood of eight of $1170(0.68 \%)$ sheep. Five had a high viral load and 3 had a low load; a persistent infection was assumed in the former, but this could not be

154 confirmed because a second blood sample was not collected. The 3 sheep with a low viral load were 155 considered transiently infected, most likely following contact with the persistently-infected sheep.

156 These 8 sheep originated from 2 large commercial flocks, which had had no abortions or births of 157 weak lambs in the past few years. It is noteworthy that the virus-positive sheep were clinically 158 healthy, which was in agreement with several reports of healthy persistently-infected lambs (Barlow et al., 1980; Bonniwell et al., 1987; Nettleton et al., 1992). Likewise, a study of Swiss sheep flocks

160 showed that the majority of BDV infections are subclinical or infected lambs only have mild clinical 161 signs that may go unnoticed. Under such circumstances, a strong economic incentive for a thorough 162 diagnostic workup may be lacking and therefore additional testing is not usually undertaken (Braun et 163 al., 2002). There is little awareness of BD among sheep farmers in Switzerland, although the endemic occurrence of this disease has long been documented (Schaller et al., 2000). Spanish studies reported similar BDV prevalences of 0.3 to $0.6 \%$ (Valdazo-González et al., 2006, 2008) and one of these, a

166 slaughterhouse study, revealed that the prevalence of BDV in individual sheep remained unchanged

167 for several years (Valdazo-González et al., 2008). Five of 21 randomly tested Spanish flocks had 168 BDV-positive sheep, yielding a flock prevalence of $23.8 \%$ (Valdazo-González et al., 2006), which 
169 was considerably larger than in the present study ( 2 of 29 flock, $6.9 \%$ ). Most sheep of the present

170 study were from breeding farms, which typically have a lower virus prevalence than commercial

171 flocks because of less animal traffic (Schaller et al., 2002).

172 The seroprevalence of BVDV in cattle before pasturing was $57.1 \%$, which was comparable to the 173 value of $57.6 \%$ previously observed in Swiss cattle (Rüfenacht et al., 2000); the BVD eradication

174 program, which was started in the same year the present study was carried out, evidently had not yet

175 affected the seroprevalence. Because of the relatively high seroprevalence, only $43 \%$ of cattle could

176 be used to investigate seroconversion, which had occurred in $25 \%$ (99) of the 396 examined cattle.

177 Because of the BVD eradication program, it is projected that the proportion of seropositive cows will 178 approach zero. The risk of seroconversion to pestivirus will therefore increase because the proportion 179 of seronegative cattle will increase, at least theoretically, to $100 \%$. The relatively large proportion of 180 negative serum neutralisation test results was most likely due to the inclusion of samples with 181 indeterminate ELISA results. Because a BVDV ELISA was used in the present study, its sensitivity 182 for BDV was expected to be somewhat reduced. Indeterminate ELISA results can also be caused by 183 non-specific serum reactions, which generate negative serum neutralisation test results. Based on high 184 titres in the serum neutralisation test, BDV infection was confirmed in 10 cattle and considered likely in 8 others, and the majority of these were from pasture $C$ where the BDV-positive sheep were the most plausible source of infection. Five others were from pasture D, which did not have any BDVpositive sheep, and reasons for seroconversion in cattle included false-negative test results in sheep, transiently viraemic sheep, premature parturition, normal delivery or abortion of persistently-infected lambs and subsequent infection of cattle, infection immediately before the start of co-pasturing and infection from wild ruminants. Wild ruminants were seen on all 4 pastures and contact between the two species was possible. However, the role of wild ruminants in the infection of cattle, sheep and goats remains unclear (Krametter et al., 2004; Vil•ek and Nettleton, 2006; Danuser et al., 2009) and despite high seroprevalences reported from a variety of countries (Lillehaug et al., 2003; Olde

194 Riekerink et al., 2005), transmission of pestivirus to domesticated cattle has not been documented 195 (Vil•ek and Nettleton, 2006). Indirect infection via vectors or fomites are theoretically possible but 196 difficult to substantiate (Houe, 1995).

197 The infection of 7 cattle with BVDV in the absence of any BVDV-positive cattle at the start of the 198 season is noteworthy. Possible reasons for this are generally the same as those used to explain the 199 infection of cattle with BDV on pasture D where there were no known carrier sheep. Because of the 200 BVD eradication program, there should be very few BVDV-infected cows in the future. Whether 201 BDV infection of cattle is clinically relevant and can produce persistently-infected calves needs 202 further study, but recent reports of persistently-infected calves from England (Cranwell et al., 2007) 
and Switzerland (personal communication, Institute of Veterinary Virology, University of Berne)

204 suggest that it can. The relationship between BVDV infection of cattle and BDV infection of sheep is

205 reminiscent of the relationship between caprine arthritis-encephalitis (CAE) of goats and Maedi

206 Visna in sheep; CAE virus can be transmitted to sheep, and Maedi-Visna virus of sheep, which is

207 closely related to the CAE-virus, can be transmitted to goats. These relationships complicate

208 serological disease surveillance (Mordasini et al., 2006).

210 Conclusions

211 This study has clearly shown that sheep grazing communal alpine pastures with cattle must be

212 considered a risk factor for the transmission of BDV to the latter, at least under Swiss farming

213 conditions. There is no doubt that cattle seropositive for BDV will complicate the BVD eradication

214 program; plans are in place for confirming seronegativity of cattle herds to BVD using milk or blood

215 samples starting as early as 2012. The ELISA test for BVD will be positive in BDV-infected cattle,

216 which will necessitate retesting using a serum neutralisation test.

218 Acknowledgements

219 We thank Dr. Josef Risi, cantonal veterinarian of Uri, Schwyz, Obwalden and Unterwalden, for his 220 support, the farmers for their help with sample collection and the staff of the Institute of Veterinary 221 Virology, University of Berne, for laboratory examinations.

\section{References}

224 Barlow, R. M., Vantsis, J. T., Gardiner, A. C., Rennie, J. C., Herring, J. A., Scott, F. M. M.:

225 Mechanisms of natural transmission of border disease. J. Comp. Pathol. 1980, 90: 57-65.

Bonniwell, M. A., Nettleton, P. F., Gardiner, A. C., Barlow, R. M., Gilmour, J. S.: Border disease without nervous signs or fleece changes. Vet. Rec. 1987, 120: 246-249.

Braun, U., Schönmann, M., Ehrensperger, F., Hilbe, M., Brunner, D., Stärk, K. D. C., Giger, T.:

231 Epidemiology of bovine virus diarrhea in cattle on communal alpine pastures in Switzerland. J. Vet. Med. A 1998, 45: 445-452.

234 Braun, U.,Hilbe, M., Ehrensperger, F., Salis, F., Alther, P., Strasser, M., Stalder, H. P., Peterhans, 235 E.: Border Disease in einem Schafbetrieb. Schweiz. Arch. Tierheilk. 2002, 144: 419-426. 
237 Büchi, R.: Epidemiologische Untersuchungen über die Ansteckung von Rindern durch mit Border-

238 Disease-Virus infizierte Schafe auf Alpweiden. Thesis, University of Zurich, 2009.

240 Cranwell, M. P., Otter, A., Errington, J., Hogg, R. A., Wakeley, P., Sandvik, T.: Detection of border 241 disease virus in cattle. Vet. Rec. 2007, 161: 211-212.

243 Danuser, R., Vogt, H. R., Kaufmann, T., Peterhans, E., Zanoni, R.: Seroprevalence and 244 characterization of pestivirus infections in small ruminants and new world camelids in Switzerland. 245 Schweiz. Arch. Tierheilk. 2009, 151: 109-117.

Houe, H.: Epidemiology of bovine viral diarrhea virus. Vet. Clin. North. Am. (Food Anim. Pract.) 1995, 11: 521-547.

Krametter, R., Nielsen, S. S., Loitsch, A., Froetscher, W., Benetka, V., Moestl, K., Baumgartner, W.: Pestivirus exposure in free-living and captive deer in Austria. J. Wildl. Dis. 2004, 40: 791-795.

Krametter-Froetscher, R., Kohler, H., Benetka, V., Moestl, K., Golja, F., Vil•ek, S., Baumgartner, W.: Influence of communal alpine pasturing on the spread of pestiviruses among sheep and goats in Austria: first identification of border disease virus in Austria. Zoonoses Public Health 2007, 54: 209213.

Krametter-Frötscher, R., Benetka, V., Möstl, K., Baumgartner, W.: Transmission of border disease virus from sheep to calves - a possible risk factor for the Austrian BVD eradication programme in cattle? Wien. Tierärztl. Mschr. 2008, 95: 200-203. ruminant alpha-herpesviruses and pestiviruses in Norwegian cervids. J. Wildl. Dis. 2003, 39: 779786. 
270 Nettleton, P. F., Gilmour, J. S., Herring, J. A., Sinclair, J. A.: The production and survival of lambs

271 persistently infected with border disease virus. Comp. Immunol. Microbiol. Infect. Dis. 1992, 15:

$272 \quad 179-188$.

Olde Riekerink, R. G. M., Dominici, A., Barkema, H. W., De Smit, A. J.: Seroprevalence of pestivirus 275 in four species of alpine wild ungulates in the High Valley of Susa, Italy. Vet. Microbiol. 2005, 108: $276 \quad 297-303$.

Peterhans, E., Bachofen, C., Stalder, H., Schweizer, M.: Cytopathic bovine viral diarrhea viruses (BVDV): emerging pestiviruses doomed to extinction. Vet. Res. 2001, 41: 44.

Reichert, C.: Infektion von Kälbern, Schafen und Ziegen mit Border-Disease-Virus. Thesis,

282 University of Zurich, 2009.

Reichle, S. F.: Untersuchungen bei Kälbern, die mit Border-Disease infizierten Lämmern zusammengehalten werden. Thesis, University of Zurich, 2009.

Rüfenacht, J., Schaller, P., Audigé, L., Strasser, M., Peterhans, E.: Prevalence of cattle infected with bovine viral diarrhoea virus in Switzerland. Vet. Rec. 2000, 147: 413-417.

Schaller, P., Vogt, H. R., Strasser, M., Nettleton, P. F., Peterhans, E., Zanoni, R.: Seroprävalenz von Maedi-Visna und Border Disease in der Schweiz. Schweiz. Arch. Tierheilk. 2000, 142: 145-153.

Strong, R., La Rocca, S. A., Ibata, G., Sandvik, T.: Antigenetic and genetic characterisation of border

299 Valdazo-González, B., Alvarez, M., Sandvik, T.: Prevalence of border disease virus in Spanish lambs. 300 Vet. Microbiol. 2008, 128: 269-278. 
Table 1: Description of communal alpine pastures.

\begin{tabular}{l|c|c|c|c}
\hline \multirow{2}{*}{ Variable } & \multicolumn{4}{|c}{ Communal alpine pasture } \\
\cline { 2 - 5 } & $\mathrm{A}$ & $\mathrm{B}$ & $\mathrm{C}$ & $\mathrm{D}$ \\
\hline Size (ha) & 250 & 200 & 800 & 350 \\
\hline $\begin{array}{l}\text { Elevation above sea level } \\
\text { (metres) }\end{array}$ & $1000-1900$ & $1500-2000$ & $1200-2300$ & $1400-2200$ \\
\hline $\begin{array}{l}\text { Length of pasture season } \\
\text { (days) }\end{array}$ & 95 & 104 & 90 & 86 \\
\hline Number of sheep & 126 & 70 & 671 & 303 \\
\hline Number of flock owners & 2 & 5 & 11 & 10 \\
\hline Number of cattle & 165 & 91 & 514 & 153 \\
\hline Number of cattle owners & 12 & 7 & 51 & 23 \\
\hline
\end{tabular}

304

305

306

Table 2: Assessment of 1170 sheep for the presence of border disease virus in blood using RT-PCR

\begin{tabular}{|l|c|c|c|c|}
\hline Pasture & A & B & C & D \\
\hline No of sheep: & $0 / 126$ & $0 / 70$ & $8 / 671$ & $0 / 303$ \\
Viremic/total & 0 & & \\
\hline
\end{tabular}

Table 3: Assessment of 99 positive or indeterminate serum neutralisation test results (cattle).

\begin{tabular}{l|c|c|c|c|c}
\hline \multirow{2}{*}{ Assessment of SNT results } & \multicolumn{3}{|c|}{ Communal pasture } & \multirow{2}{*}{ Total } \\
\cline { 2 - 6 } & $\mathrm{A}$ & $\mathrm{B}$ & $\mathrm{C}$ & $\mathrm{D}$ & ( \\
\hline Antibody not differentiated & 3 & 0 & 36 & 8 & 47 \\
\hline SNT negative & 3 & 3 & 17 & 4 & 27 \\
\hline BDV infection confirmed & 0 & 0 & 7 & 3 & 10 \\
\hline BDV infection likely & 0 & 0 & 6 & 2 & 8 \\
\hline BVDV infection confirmed & 0 & 0 & 2 & 2 & 4 \\
\hline BVDV infection likely & 0 & 0 & 2 & 1 & 3 \\
\hline
\end{tabular}

311 SNT, Serum neutralisation test

312 BDV, Border disease virus

313 BVDV, Bovine viral diarrhoea virus 
314 